\title{
CERAMICS
}

In an instructive paper on "Ceramic Objects of Pure Materials" published in Zeitschrift für angewandte Chemie, the author insists on the finest subdivision of the materials when it is intended to prepare "tun-walled" refractory objects. His materials are the rare earths, magnesia, alumina, carbides, silica, etc., and especially also the nitrides of boron and titanium which he has been studying. The calcined materials should be crushed to grains of I. $\mathrm{mm}$. and then ground down in steel mills to powders of particles of from 0.001 to $0.005 \mathrm{~mm}$. Though this extreme subdivision seems to undo what has been gained by calcination of the briquetted materials, he considers that the uniformity obtained increases the strength of the objects and reduces the tendency to shrinkage. As binding materials, he recommends water, colophony, oils of turpentine, celloidin in amyl acetate, bakelite varnish, glycerine, and caramel. The last two he prefers, for example, for thoria, and describes how zirconia can be provided with a glazing of thoria. The preparation of boron nitride from boric anhycride and, similarly, of titanium nitride, is an elaborate process. The oxide turns into the nitride when heated at $1200^{\circ} \mathrm{C}$. in an atmosphere of ammonia, but the presence of water, which is difficult to expel, interferes with the reaction and the first formed superficial coating of nitride prevents further access of ammonia; high pressure also accelerates the reaction. Mixed with paraffin, the nitride can be squirted into threads $0.1 \mathrm{~mm}$. in diameter. The resulting nitrice stands $2,000^{\circ} \mathrm{C}$. quite well, and is used for making the tubes in which granular carbon resistances are baked. The boron nitride, density 1.92 , does not melt in the arc burning in an atmosphere of nitrogen: it is, however, attacked by oxygen and also by boiling water, especially if a little boron anhydride should still be left in it. $-\mathrm{M}$.

\section{BRITISH BOARD OF TRADE}

During the month of September the British Board of Trade received inquiries from firms in the United Kingdom and abroad regarding sources of supply for the following articles. Firms which may be able to supply information regarding these things are requested to communicate with the Director of the Commercial Intelligence Branch, Board of Trade, 73 Basinghall St., London, E. C.

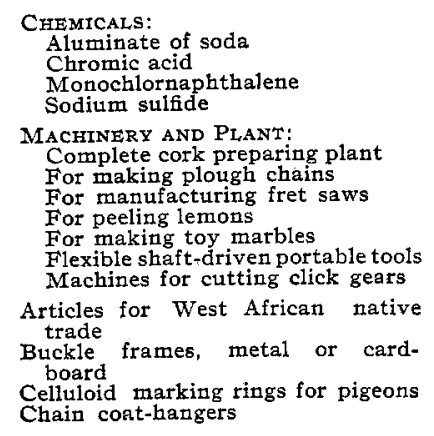

Chamois leather Curling irons, cheap Curling irons, cheap
Electric driven machinery for
floor-polishing Eucalyptus red gum
Glove makers' waste Leather waste, $i$. e., bucks, chamois, suede, etc. Manioc flour Paper knives, bone and ivory Piercing saws for metal Powder for making beer Skins, kid Soap boxes, metal Synthetic essential oil of mustard Thimbles, steel and silvered Wood preservative not containing coal-tar oils ooden shovels for margarin factories -M.

\section{MANGANESE STEEL}

A catalog issued by Allen \& Co,, of Sheffield, England, relates to their Imperial manganese steel and to its use, especially for parts of dredgers, crushing machines and conveyors where great resistance to wear and abrasion are required. This steel is so hard that it cannot be machined and must be finished by grinding and, at the same time, is so tough that it may be bent double while cold without fracture. It has a tensile strength of 55 tons per sq. in., or over, with an elongation of about 40 per cent in 4 in., and is non-magnetic. It is supplied in castings, rolled bars, sheets, forgings and patent rolled rails.- $M$.

\section{HARDENING OF ALUMINUM BRONZE}

According to an article in the Giesseri Zeitung for June I, aluminum bronzes can be improved by thermal treatment. When they contain less than 7 per cent copper, the thermal treatment will not affect the properties much. Higher grade bronzes can be hardened, however, and by the further addition of iron, silicon and other elements, the mechanical properties of the alloys can be much varied. Thus, e. g., bronzes can be prepared having a Brinnell hardness of roo without being brittle. An aluminum bronze resembling in its mechanical properties a 0.35 carbon Swedish steel was given hardness values ranging from 100 to 260 by various thermal treatments; such bronzes of great hardness will answer as bearing metals even for high speeds. The following figures are given as to the properties of a Io per cent aluminum bronze containing some titanium, the percentage of which is not quoted:

$\begin{array}{lccc}\text { Bronze } & \begin{array}{c}\text { Quenched } \\ \text { as cast }\end{array} & \begin{array}{c}\text { After Thermal Treatment } \\ \text { at Different Temperatures }\end{array} \\ \text { Limit of Elasticity... } & 9.6 & 19.8 & 27.7 \text { to } 19.2 \mathrm{~kg} \text {. per cm2. } \\ \text { Tensile Strength.... } & 51.8 & 73.6 & 67.7 \text { to } 64.4 \mathrm{~kg} \text { per cm. } \\ \text { Elongation........ } & 19.5 & 1.0 & 5.5 \text { to } 1.4 \text { per cent } \\ \text { Contraction of Area. } & 33.7 & 0.8 & 9 \text { to } 18.5 \text { per cent } \\ \text { Brinnell Hardness... } & 100 & 262 & 158 \text { to } 140\end{array}$

\section{POTASH FROM FLUE DUST}

A recent article by Mr. H. T. Cranfield in the Journal of the Board of Agriculture deals with the extraction or potash salts from blast furnace flue dust. The number of furnaces in full blast in Britain, the author reckons to be 300 , and the quantity of flue dust produced per week works out at 20 tons black dust, 5 tons red and $I$ ton cream colored. On the assumption that the black dust contains 2.5 per cent, the red 7 per cent, and the cream io per cent, each furnace would yield about 50 tons of potash per annum, giving an annual production of 15,000 tons. At least 50 per cent of this would represent soluble potash. From these figures, this may be regarded as an important source of potash and until arrangements can be made and plant erected for the extraction of the water-soluble potash salts, Mr. Cranfield suggests that the raw flue dust might be used on land deficient in potash in the past two years.-M.

\section{A NEW TEST PAPER}

A very delicate test paper has been prepared in Japan from the fruit of the Tama-tsubaki, which has a violet color and is turned to greenish blue by a mere trace of alkali and to red by an extremely dilute acid solution. The plant is also known in Japan as Nezumimochi or Teratsubaki. The inventor noticed that the color of its fruits never fades, while the color of the flowers quickly fades. He squeezed the fruit and dyed a filter paper with the juice which gave a violet shade. $-\mathrm{M}$.

\section{FERRO-CONCRETE SHIPS}

During the past three months, says the Times Engineering Supplement, No. 515, the Committee of Lloyd's Register of Shipping have approved plans for the construction in ferroconcrete of a number of non-propelled barges, some designed to carry 500 tons dead weight, and also of a motor vessel. These vessels will be built in the United Kingdom and in Norway, under the inspection of the Society's surveyors, and are intended for the British and Scandinavian coastal trade. Plans of other ferro-concrete vessels of larger capacity for certain sea trades are at present under consideration. One of the society's principal surveyors recently made a tour of inspection in Scandinavia, where, owing to circumstances arising from the war and other causes, the use of ferro-concrete for ship construction has so far been most developed and the report of his visit has naturally placed the Committee of Lloyd's Register in possession of valuable data on the subject.-M. 